\title{
Discussion on the Strategy of Construction of the Library Culture
}

\author{
Zengzhang Yang \\ Library of Shandong Women's University, Jinan, Shandong 250300, China \\ wuyegl@163.com
}

\begin{abstract}
The library culture is created by the long-term social practice and the integration of the material culture and the mental culture, including three layers of material culture, the system culture and the mental culture. Constructing the library culture will help advance the core competitiveness, and build up the good image of the library, promoting the harmonious development in interpersonal relationship. Construction of the library culture should be mainly focused on core value building, cooperation awareness strengthening, reasonable system establishing, the library image shaping, and people-oriented and humanized management.
\end{abstract}

Keywords: the library, the library culture, people-oriented.

\section{Introduction}

The library construction and development originate from the culture, serving for cultural development and having formed the unique culture featured by itself in the long-term existence and development. The conception of the library culture was first proposed by the American books management scholars as an emerging managerial philosophy in 1980s, which was thought highly of by the international community [1]. The library culture sums up the managerial thoughts, value systems, behavior regulations and rules complied by total staff. It is coming into being gradually with the long-run construction and development under the certain substantial condition. The library culture has been playing a significant role during the library development. The brilliant library culture is the soul and intangible property penetrating in every respect of the library, to play a significant role in retaining and pushing forward the library existence and development.

\section{The Essential Connotation of the Library Culture}

With influence of factors of society, politics, culture and economy etc within a certain historical phase, the library culture is formed gradually in the long-term social practice, integrating with the material and mental results by the library founder. The library culture includes three layers: the material culture, the system culture and the mental culture. The three layers are explained from the exterior to the interior and from the phenomena to the essence. The library culture is based on the material culture, guaranteed by system culture and centered by mental culture [2], as is shown in figure 1. 


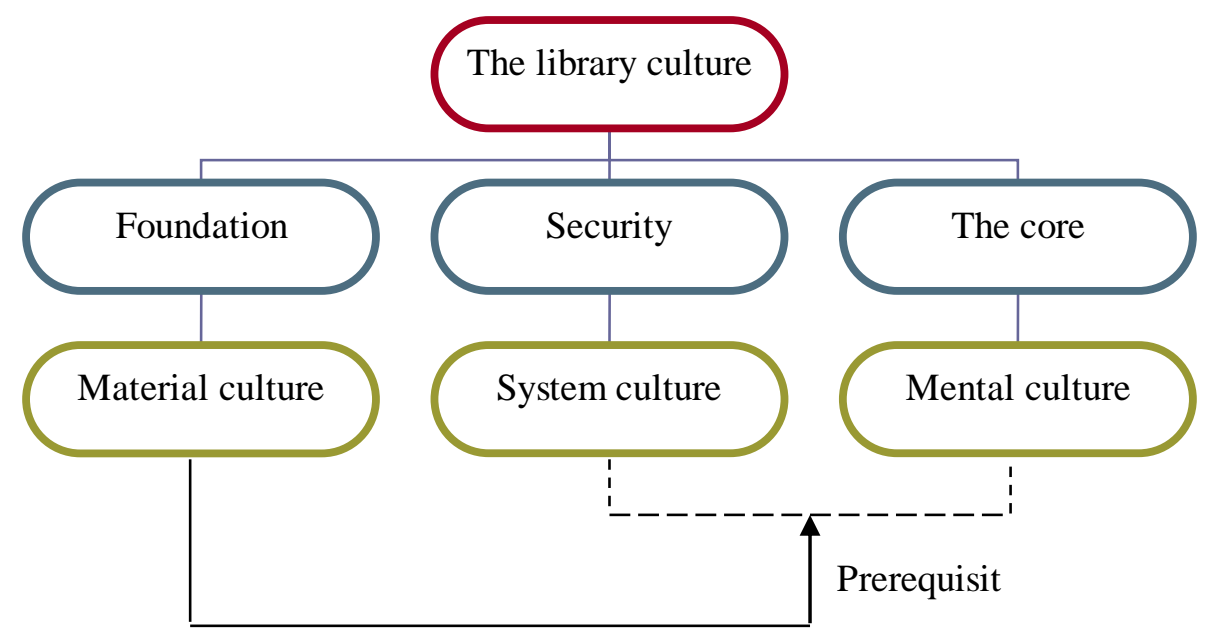

\subsection{The Material Culture of the Library}

Figure 1. Layers of the library culture

The material culture of the library is unfolding the library's phenomena and formation. It is the basis of the library culture and the material condition and the security for the mental culture and the system culture, as well as the outer symbol. The material culture mainly includes the construction of the building and the infrastructure and the equipment, the book collections resource and the environment and the atmosphere, as is shown by table 1 .

Table 1 . The material culture of the library

\begin{tabular}{|c|c|c|}
\hline \multirow{4}{*}{$\begin{array}{c}\text { The material culture of } \\
\text { the library }\end{array}$} & $\begin{array}{c}\text { The building, equipments } \\
\text { and facilities }\end{array}$ & Practical, aesthetical, well-equipped \\
\cline { 2 - 4 } & Book collections resource & $\begin{array}{c}\text { Abundant paper bibliographies, digital } \\
\text { resources and media resources }\end{array}$ \\
\cline { 2 - 4 } & $\begin{array}{c}\text { The environment and the } \\
\text { atmosphere }\end{array}$ & $\begin{array}{c}\text { Creating the happy and comfortable } \\
\text { environment }\end{array}$ \\
\hline
\end{tabular}

\subsection{The System Culture of the Library}

The system culture lies in the middle layer of the library culture, which will function as disciplining and restricting behaviors of readers. It mainly includes criteria in the field of library, the business management system and the administrative management system etc, disciplining and restricting the material culture and the mental culture. The reasonable regulations, the strict discipline and the scientific management are the important security for the construction of the library culture and the library management scientization.

\subsection{The Mental Culture of the Library}

The mental culture of the library refers to the library value system with the core of the values and the behavior way decided by it. The mental culture of the library is the core and soul of the library culture, intensively reflecting the essence and the characteristics of the library. The mental culture is mainly including the library values, the library spirits, the library image and the library ethics, as is shown by table2.

Table 2. The mental culture of the library

\begin{tabular}{|c|c|c|}
\hline \multirow{4}{*}{$\begin{array}{l}\text { The mental culture of the } \\
\text { library }\end{array}$} & $\begin{array}{c}\text { The library } \\
\text { values }\end{array}$ & The basic beliefs and rules \\
\hline & $\begin{array}{l}\text { The library } \\
\text { spirit }\end{array}$ & $\begin{array}{l}\text { The reasonable integration of scientific spirit and } \\
\text { humanistic spirit }\end{array}$ \\
\hline & $\begin{array}{l}\text { The library } \\
\text { image }\end{array}$ & The overall impression and the evaluations by readers \\
\hline & $\begin{array}{l}\text { The library } \\
\text { ethics }\end{array}$ & $\begin{array}{c}\text { The integration of ethical values, ethical qualities and } \\
\text { ethical behavior rules }\end{array}$ \\
\hline
\end{tabular}




\section{The Critical Significance of Construction of the Library Culture}

\subsection{Constructing the Library Culture to Advance the Core Competitiveness of the Library}

The core competitiveness is a competence to create the service with its own characteristics and enhance its real ability contending in the information market through the accurate analysis and forecast to grasp the readers' demands, and working on the combination of the knowledge, technology, information, management, culture and staff. Constructing the library culture will transform the quality and function of elements in the library core competitiveness into a advantageous combination, thereby advancing its core competitiveness [3]. It generalizes the science and technology, and knowledge of humanistic society into the personal comprehensive quality of the librarian. With the librarian as the carrier of the information, knowledge, technology and intelligent services, they will take good effect to inject the power and vigor for the library development, advancing the competitiveness edge.

\subsection{Constructing the Library Culture to Be Conducive to a Good Library Image Establishment}

The construction of the library culture is the continuous image shaping of the library. The public image of the library among the readers depends on advertising, as well as on personal action more. The library culture has its values, conceptions and behavior rules penetrated gradually into all the staff through conducting and communicating etc, combining the personal goal with the integral goal of the library, which will get them rallied to maintain the library image. Librarians will send messages to the society to make readers a relatively integrated knowing of the library services, information, environment, facilities and staff, helping the good library image building and enhancing the readers' praise and credit.

\subsection{Constructing Library Culture to Improve the Harmonious Development of the Interpersonal Relationship}

The harmonious interpersonal relationship is the crux of the successful interior management of the library. Construction of the library culture will increase the communication between librarians, reduce the beneficial arguments, boost the coordination between departments and form the democratic and harmonious working atmosphere, so that the initiative, positivity and creativity will be fully motivated, forming the centripetal force.

\section{The Strategy of Library Culture Construction}

\subsection{Establish the Core Values of the Library for Readers}

Library values are the group awareness that the library and all the librarians have the common responsibility to guide the work of the library. It is the judgment of the value of the objective things, the core position in the library culture system, and the enhancement of the cohesion and competitiveness of the library. It is important to be the guide for the survival and development of the library [4].

All for the reader, service dedication, resource sharing, and people-oriented concept should become the core values of modern library content. Serving for readers is at the heart of library values. Library as an information service organization, its basic responsibility is to provide readers with satisfactory information products and services, management and management of the library, so that the best allocation of library resources and portfolio, deepen the service content to maximize the output efficiency.

\subsection{Strengthen the Team Awareness of Librarians}

In order to strengthen the team consciousness of the librarians, it is necessary to determine the objectives and guidelines of the library service and to clarify the code of conduct and the rights and obligations that each member of the library should follow to achieve the goal. At the same time, we must strengthen the democratic management and encourage the librarians to participate in the library Management, decision-making and activities, from all aspects to enhance the sense of ownership of librarians. It is clear that librarians, as managers of the library, can not just focus on their own self-design, self-improvement, self-development; it should focus on the social, library material and spiritual environment, promoting social and library material culture and the continuous development of 
spiritual culture, to their own continuous development to create more favorable social conditions and a broader prospect.

\subsection{Establish a Reasonable Library Rules and Regulations}

The library system is the library procedure and the library staff and the reader use the library action guidelines. In the construction of the library system, we should base on the actual needs of the library, according to the actual needs of the library, develop and revise the rules and regulations. According to the librarians' ideas, educational level and operational ability, the contents of the rules and regulations are formulated so that they can better understand and implement the rules and regulations. It is required to learn from the advanced experience of domestic and foreign counterparts, combined with the actual museum, to develop practical and effective terms. In the construction of the library system, we should fully reflect the "people-oriented" management thinking. To reflect the equality, respect for the position, for the reader to bring more humanistic care, while encouraging librarians to play a personal initiative and enthusiasm.

\subsection{Create a Good Library Image}

The image of the library is the overall impression and overall evaluation of the library by the readers and librarians. The image of the library is the explicit of the library culture; its essence is the credibility of the library. The image of the library reflects the status and reputation of the library, with the role of inspiring librarians.

The image of the library needs to do the service for the reader, the need for all librarians work together, work hard, keep making progress. Only to provide readers with high quality, convenient, efficient, and user-friendly services, in order to improve the visibility of the library, credibility, to win the reader's identity. Good library image should not only fully convey the values of the library, but also fully reflect the library's humanities and service purposes.

\subsection{People-oriented, the Implementation of Human Management}

The core elements of modern management philosophy are human management. Humanized management is to highlight the status of people in the management, people-oriented, to achieve people-centered management, including librarians and readers.

The main body of the library is the librarian, the librarian's potential and the overall quality level of the librarian team, which restricts the management level of the library. In the management to reflect the "librarian first" principle, advocate respect for people, care for people, understand people, care about people, attention to the development needs of librarians and personal values to achieve the "people-oriented" management philosophy implemented [5].

To firmly establish the "readers first, service first" a principle of service. Librarians and librarians should understand readers, pay attention to readers, respect readers, and strive to meet the needs of readers. Put all kinds of readers into the real emotional care, to provide readers with active, enthusiastic and thoughtful service, broaden the communication channels, and readers to establish and maintain close contact.

\section{Conclusion}

Library culture is the soul of the library, excellent library culture, to create a positive, harmonious, progressive work atmosphere; the development of the library business has played a huge role in promoting and promoting. The construction of library culture should pay attention to the construction of material level and system level, but should pay more attention to the construction of spiritual level. The core idea of library culture is people-oriented thinking. In the construction of library culture, we should always "people" on the focus, to promote human management humanistic care.

\section{References}

[1] Hu Chunxiang. Orientation of the University Library's Cultural Function under the Cultural Globalization [J]. Library Development, 2015(4):21-24. 
[2] Li Hong-qi. Research on Cultural Construction in University Libraries [J]. Journal of Library and Information Sciences in Agriculture, 2012(1): 71-74.

[3] Ke Ping, Yan Hui. Research on the Theory of Library Culture [J]. Library Tribune, 2005(6):77-83.

[4] Jiang Xiang-hong. On the Structuring of Library Culture [J]. Library Tribune, 2000(8):11-14.

[5] Cheng Yuan. On Library Cultural Construction [J]. Library Information, 2011(4):116-118. 